\title{
Regulation - the area of inter-branch knowledge application
}

\author{
Sergey Mikhailovich Zyryanov ${ }^{1,21}$ and Anastasia Valentinovna Kalmykova ${ }^{1,3}$ \\ ${ }^{1}$ The Institute of Legislation and Comparative Law under the Government of the Russian Federation, \\ Department of Administrative Law and Procedure, Moscow, Russia \\ ${ }^{2}$ Plekhanov Russian University of Economics, Scientific laboratory "Analysis of Law Enforcement \\ Practice in the Economy of the Russian Federation", Moscow, Russia \\ ${ }^{3}$ HSE University, Department of Legal Regulation of Business, Moscow, Russia
}

\begin{abstract}
The purpose of the study is to justify the feasibility of using regulatory policy and sectoral scientific tools in the daily activities of regulatory bodies. The study used a wide range of sources containing empirical data reflecting modern theoretical concepts of regulation. The authors used general scientific and special methods of cognition, methods of analysis and synthesis, formal logic, comparative jurisprudence, and interpretation of law. The result of the study was an overview of the points of view of modern scientists on regulation problems and the use of an intersectoral approach. In addition, the article provides a rationale for the need to use an intersectoral approach in regulation; the possibilities of attracting psychologists and criminologists, historians and political scientists have been identified. The novelty of the results obtained is due to the author's approach to the study of the activities of regulatory bodies and lies in the fact that it has shown that in modern conditions, regulation takes on the character of scientific activity that requires broad knowledge. Currently, in the world practice, there are no examples of the inclusion of criminologists, political scientists, historians, sociologists, and ecologists in the staff structure of regulatory bodies as experts on a wide range of issues that managers have to solve when developing regulatory policy, choosing models, and developing regulatory strategies. Nowadays, all these issues are solved by the heads of regulatory bodies mostly intuitively, guided by their life experience and ideas about what should be done or subjective assessments, which does not contribute to the successful achievement of regulatory goals. Continuation of research on this topic will contribute to the development of theoretical ideas about the activities of regulatory bodies and the development of practical proposals aimed at increasing the efficiency and effectiveness of regulation.
\end{abstract}

Keywords: government, regulation, performance, risk assessment

\section{Introduction}

\footnotetext{
${ }^{1}$ Corresponding author: zyryanov.s@gmail.com
} 
The complexities of the formation and implementation of regulatory policy attract the attention of representatives of various branches of scientific knowledge. Not only lawyers and economists turn to the study of relations related to regulation, but also criminologists, political scientists, and representatives of other social sciences.

Regulation is the most important function of a modern state. By providing a remedy for markets failure, regulators set requirements, issue permits, provide, where necessary, various preferences and benefits, monitor and enforce compliance with these requirements for those who do not wish to do so voluntarily. The emergence of new knowledge, new products, and new technologies affects not only regulated relations, but also the activities of regulators. Quite recently, a sanitary inspector came to the meat processing plant with a sharp stick and checked the safety using the "poke and sniff" method, but now microbiology, spectral and genetic analysis are available to him. Regulation is turning into a complex process of complex research of a scientific level and the adoption of regulatory acts based on the analysis of a huge amount of data.

In recent years, in science and practice, attention to regulation problems has increased [1], new methods, organizational structures are being developed, and methods of managing commercial institutions are being adopted [2-4].

Special knowledge in psychology, criminology and behavioural economics is the most popular $[5-7,8]$. The study of practice, including the experience of other regulators, and the use of the tools of historical science are of great importance $[9,10]$. The regulator is under constant pressure from politicians and other stakeholders, the patterns of interaction with which are the subject of political science $[11,12]$.

The authors proceed from the premise that guided by discipline-specific knowledge it is impossible to successfully regulate complex relations, predict and prevent dangerous situations in a timely manner, it is necessary to use the tools available in the arsenal of jurisprudence, economics, psychology and criminology, sociology, history, and political science.

Since the purpose of the article is to develop ideas about the use of an intersectoral scientific approach in the practice of regulators, its achievement includes the following tasks: substantiating the need to use an intersectoral approach in regulation; defining the limits of the use of criminological scientific knowledge; assessment of the role of the historian in the activities of the regulator; determination of the place of political scientists in the staff of the regulator.

The information and analytical basis of the study consists of information materials presented on the official websites of governments, government departments, and regulatory agencies. In addition, the authors studied and used the materials that characterize the implementation of regulatory reforms over the past decades. The selection of sources was carried out in accordance with the principles of relevance, timeliness, and approbation in the scientific environment.

The methodological basis of the research consists of general scientific and special methods of cognition, including methods of analysis and synthesis, formal logic, comparative jurisprudence, and interpretation of law. The presented study is a continuation of the work of the authors on the study of regulation problems and the implementation of state control $[13,14]$.

\section{Results}


The results of the study can be presented in the form of a table, in the left column of which are presented the branches of knowledge that may be in demand in regulation, and in the right - the possible directions of using this knowledge.

Table. The results of the study.

\begin{tabular}{|l|l|}
\hline $\begin{array}{l}\text { Knowledge } \\
\text { industry }\end{array}$ & Areas of use in regulatory activities \\
\hline $\begin{array}{l}\text { Industry } \\
\text { sciences }\end{array}$ & $\begin{array}{l}\text { Identification of risks, development of standards, technical means of } \\
\text { diagnostics and control }\end{array}$ \\
\hline $\begin{array}{l}\text { Administrative } \\
\text { law }\end{array}$ & $\begin{array}{l}\text { Development and approval of regulatory legal acts, establishment of } \\
\text { licensing, control procedures, prosecution and punishment }\end{array}$ \\
\hline Criminology & $\begin{array}{l}\text { Search for means of effective influence on regulated people, measures } \\
\text { of persuasion and coercion, choice of regulatory strategies }\end{array}$ \\
\hline Story & $\begin{array}{l}\text { Studying the experience of the regulator, analysing past mistakes and } \\
\text { successful actions }\end{array}$ \\
\hline $\begin{array}{l}\text { Political } \\
\text { science }\end{array}$ & $\begin{array}{l}\text { Studying the political situation, finding compromises between the } \\
\text { goals of regulation and the requirements of politicians and voters, } \\
\text { developing their own regulatory policy. }\end{array}$ \\
\hline
\end{tabular}

\section{Discussion}

Modern technologies, on the one hand, equip regulators with new tools that allow them to achieve greater compliance, identify key risks and target them in a targeted manner; on the other hand, they create new problems. Along with markets failures, regulations failures also arise which explain catastrophic oil spills and banking crises. Regulatory failures are more expensive for the government, society and companies [15-17]. Regulation failures indicate ineffective market intervention. Therefore, the requirements for regulators are also constantly increasing. The main conditions for the ability of the regulator to solve their problems are knowledge and ability to collect and process information, identify and assess risks, predict possible changes to make decisions on risk management, assess the costs and benefits of decisions, and promptly intervene to prevent dangerous events.

Success is determined by the setting of the work of the regulators themselves, the formulation of the mission, the setting of goals and objectives, the motivation of employees and their qualifications, the assessment of their activities and the level of internal control. It is necessary to understand the problems associated with production, organization, dissemination of knowledge necessary to make qualified decisions in the field of specific risks management [1].

Regulation requires scientific methods and approaches to decision-making; it is impossible without narrow specialization in the fields of scientific knowledge. Otherwise, it is impossible to ensure quality, efficiency, management productivity, and to achieve socially significant regulatory goals $[2,3,18]$. The weight of each risk can only be determined using specific knowledge based on a risk management model. This requires experts with special knowledge in the implementation of risk-oriented approaches, i.e. risk managers [4].

This is rarely taken into account by leaders. Decisions are made either intuitively, or they are guided by proposals prepared by like-minded experts, although rival schools and competing ideas coexist in science, and the opinion of one scientist may not coincide with the opinion of another one. For successful regulation, it is necessary to involve representatives of different branches of knowledge, and even representatives of different scientific schools. 
Regulation affects the entire community. The regulator sets mandatory requirements, monitors compliance with these requirements and ensures compliance. They use the full range of state coercion methods. People can either comply with the requirements voluntarily and deliberately, under pain of responsibility, or not comply hoping that this violation will not be discovered, that they will be able to agree with the inspector. Non-compliance for principled reasons has led to the formation of a special type of corporate culture of countering regulation $[7,19]^{2}$.

The patterns of human behaviour in this area are studied by criminologists and psychologists. However, as William K. Black rightly notes, there is no full-time criminologist position in any regulatory body [5], although the purpose of regulation is to create lawful behaviour, voluntary and informed compliance, and minimize litigation. The methods proposed by experts in behavioral economics [6, 20, 21, 23] like influencing regulated people, using shame, public condemnation, and the idea of damage to business reputation should be taken into account.

The regulator's decisions, even for new areas (green energy, digital economy), should be based on accumulated experience and the analysis of its effectiveness and efficiency. The regulator must know what explains the regulation failure and not repeat past mistakes. This is especially important when making decisions on an emergency basis. Conclusion: The regulatory body should have its own in-house historian [1], which allows for a systematic assessment of the changing context of organizations, communities and policies within which professional decisions are planned [9].

The regulator's decisions are a compromise between political requirements and their own independence, the goal of the mission. The development of regulatory policy is a complex task in itself, involving a political choice of one of several possible solutions, the choice of strategies, regulatory models, specific methods and tools, wherein a full-time political scientist could help.

Finally, to successfully achieve regulatory goals, special knowledge of sociologists, social psychologists, and management specialists is required who can help organize the activities of the regulatory body and motivate employees, implement a performance-management system [10, 12], and involve members of the public and regulated entities in the development of regulatory decisions [11].

\section{Conclusion}

The study has shown that in modern conditions, regulation takes on the character of scientific activity requiring broad knowledge. Currently, in the world practice there are no examples of including criminologists, political scientists, historians, sociologists or ecologists in the staff structure of regulatory bodies as experts on a wide range of issues that managers have to solve when developing regulatory policy, choosing models, and developing regulatory strategies. Nowadays, all these issues are solved by the heads of regulatory bodies mostly intuitively guided by their life experience, ideas about what should be done and subjective assessments, which does not contribute to the successful achievement of regulatory goals.

Proceeding with the research on this topic will contribute to the development of theoretical ideas about the activities of regulatory bodies and the development of practical proposals aimed at increasing the efficiency and effectiveness of regulation.

${ }^{2}$ Its meaning is that improperly designed regulation can lead to a kind of regulatory perversion, i.e. to the emergence of a criminal environment in the regulated industry 


\section{References}

1. D. Levi-Faur, Achieving Regulatory Excellence, 225-234 (Cary Coglianese, Brooking Institution Press, Washington, 2017)

2. H. Rothstein, O. Borraz, M. Huber, Regulation and Governance, 7(2), 215-235 (2013). https://doi.org/10.1111/j.1748-5991.2012.01153.x

3. S.V. Berg, Best Practices in Regulating State-Owned and Municipal Water Utilities, (Untitled Nations Economic Commission for Latin America and the Caribbean, Santiago, 2013)

4. D.A. Moss, When All Else Fails: Government as the Ultimate Risk Manager (Harvard University Press, Cambridge, 2004)

5. W.K. Black, The Criminologist, 29, 1-4 (2004)

6. J. Braithwaite, British Journal of Criminology, 40(2), 222-238 (2000)

7. J.A. Consiglio, Insights on Financial Services Regulation, 93-97 (Emerald Publishing Limited, West Yorkshire, 2020). https://doi.org/10.1108/978-1-83982-066-320201012

8. D.H. Bayley, C.D. Shearing, Law and Society Review, 30(3), 585-606 (1996). http://dx.doi.org/10.2139/ssrn.2726571

9. C. Abbott, S. Adler, Journal of the American Planning Association, 55, 467-473 (1989)

10. C.M. Radaelli, SSRN Electronic Journal (2016). http://dx.doi.org/10.2139/ssrn.2882119

11. D. Hutton, The Role of Stakeholder Relationships in Regulatory Excellence. RegBlog, (2015). Accessed on: June 12, 2020. [Online]. Available: www.reg-blog.org/2015/07/27/hutton-regulatory-excellence/

12. F. Schauer, The Force of Law (Harvard University Press, Cambridge, 2015)

13. S.M. Zyryanov, A.V. Kalmykova, IJEBA, 8(1), 84-91 (2020). https://doi.org/10.35808/ijeba/507

14. S.M. Zyryanov, A.V. Kalmykova, Public Administration Issues, 3, 31-66 (2019). Accessed on: June 12, 2020. [Online]. Available: https://vgmu.hse.ru/2019--3/308936720.html

15. C. Wolf Jr., Journal of Public Policy, 7(1), 43-70 (1987)

16. H. Cooney, Australian Resources and Energy Law Journal, 39(2) (2020). Accessed on: June 12, 2020. [Online]. Available: https://ssrn.com/abstract=3736718

17. I. Keay, Regulating Natural Monopolies in Canada, in J.R. Baldwin, Regulatory Failure and Renewal, the Evolution of the Natural Monopoly Contract (2020). http://dx.doi.org/10.2139/ssrn.3716335

18. B.L. Garrett, M.T. Stevenson, Behavioral Sciences \& the Law. Duke Law School Public Law \& Legal Theory Series No. 2020-41 (2020). Accessed on: June 12, 2020. [Online]. Available: https://ssrn.com/abstract $=3615742$

19. E. Bardach, R. Kagan, Going by the Book: The Problem of Regulatory Unreasonableness (Temple University Press, Philadelphia, 1982)

20. C.R. Sunstein, Hayekian behavioral economics (Published online by Cambridge University Press, 2020). http://dx.doi.org/10.2139/ssrn.3714750

21. X. Gabaix, Behavioral Inattention, CEPR Discussion Paper No. DP13268 (2018). Accessed on: June 12, 2020. [Online]. Available: https://www.nber.org/papers/w24096 